\title{
Investigation the role of social capital, social support and psychological hardiness in predicting life quality of elderly women
}

\author{
Ashoori $\mathrm{J}^{1}$
}

\begin{abstract}
Introduction and purpose: Quality of life can be affected by several psychological factors including social capital, social support and psychological hardiness. Therefore, this research aimed to investigate role of social capital, social support and psychological hardiness in predicting older women quality of life.
\end{abstract}

Materials and Methods: This study used cluster sampling method to select 250 older women living at Gharchak City in 2014. Data were collected using series of self-reported questionnaires including social capital, social support, psychological hardiness and quality of life scales. Data were analyzed by SPSS-19 using Pearson correlation and hierarchical multiple regressions.

Findings: Our findings showed a mean score of $2.86(\mathrm{SD}=1.09)$ for quality of life which is considered as a middle level quality. In addition, we found positive and significant $(\mathrm{P}<0 / 01)$ relationships between older women quality of life and social capital $(\mathrm{r}=0.46)$, social support $(\mathrm{r}=0.52)$ as well as psychological hardiness $(\mathrm{r}=0.39)$. Further analysis revealed that $54 \%$ of older women quality of life variance can be explained by social capital, social support and psychological hardiness.

Conclusion: This study showed that part of older women's quality of life can be affected by social capital, social support and psychological hardiness. Therefore, it is recommended to design and implement suitable programs to improve older women quality of life.

Key words: Social Capital, Social Support, Psychological Hardiness, Quality of Life, Older Women

Copyright (C) 2018 Quarterly Journal of Geriatric Nursing.This is an open-access article distributed under the terms of the Creative Commons Attribution international 4.0 International License(http://creativecommons.org/licenses/by /4.0/) which permits copy and redistribute the material, in any medium or format, provided the original work is properly cited.

1 - PhD of Psychology, Department of Psychology, Isfahan (Khorasgan) Branch, Islamic Azad University, Isfahan, Iran. (Corresponding Author):E-mail: Jamal_ashoori@yahoo.com 


\title{
بررسى نقش سرمايه اجتماعى، حمايت اجتماعى و سخت رويى روانشناختى در يِيش بينى كيفيت زندكى زنان سالمند
}

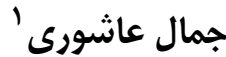

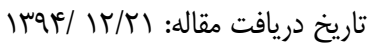

تاريخ پذيرش مقاله: •r/ ع / هوس

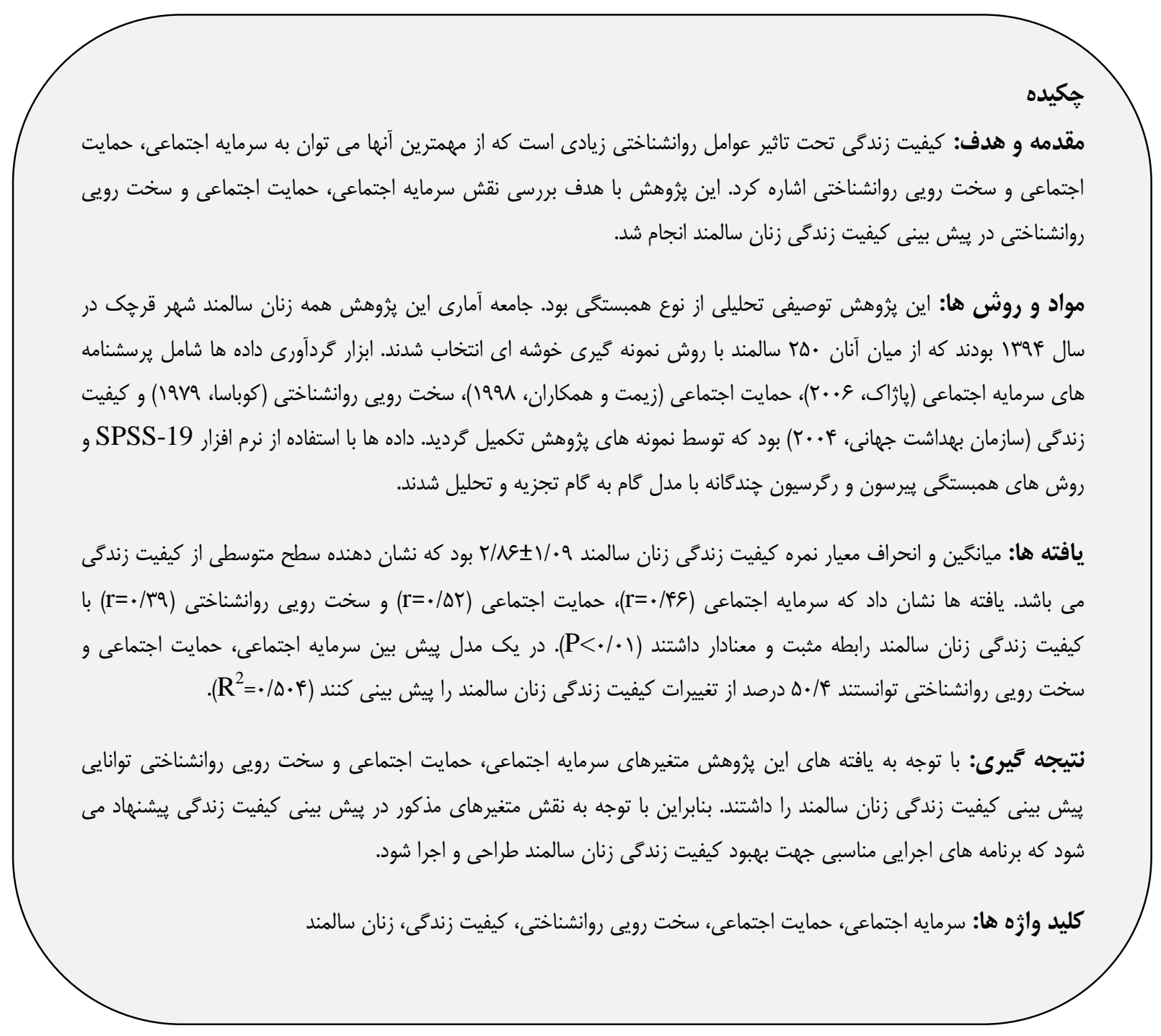

1- دكترى روانشناسى، دانشخاه آزاد اسلامى، واحد اصفهان (خوراسگان)، تروه روانشناسى، اصفهان، ايران (نويسنده مسؤول). يَت الكترونيكى: Jamal_ashoori@yahoo.com 
باشد (و). سرمايه اجتماعى بــه عنـوان وجـوهى از شـبكه هـا و هنجارهاى زندگى اجتمـاعى اسـت كـهـ بـهـ مشـاركت كنــدكان توانايى عمل موثر در جهت تحقق اهداف مشترك مى دهــ (V). سرمايه اجتماعى ميراث روابط اجتمـاعى اسـت و فعاليـت هـاى جمعى را تسهيل مسى كنــــ و دربر گيرنسـه اعتمـاد، هنجارهـاى مشاركتى و شبكه هايى از يِيوندهاى اجتماعى اسـت كـه باعث دور هم جمع شدن افراد به صورت منسجم و با ثبات بـه منظـور تامين هدفى مشترك مى شود (^). نتايج يـرُوهش هـا حـاكى از

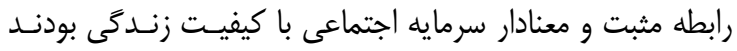

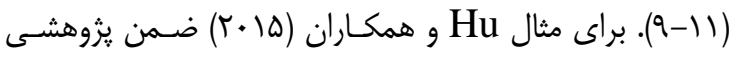
درباره رابطه بين سرمايه اجتماعى و كيفيت زندگى به اين نتيجه رسيدند بين سرمايه اجتمـاعى و كيفيـت زنـدكَى رابطـهـه معنـادار مستقيم وجود داشت (·) (1). همجنــين عليـزاده اقـدم و همكـاران (rqسו) ضمن يزوهشى با عنوان بررسى رابطه سرمايه اجتماعى

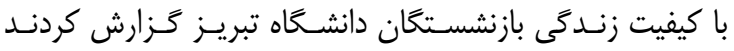
سرمايه اجتماعى با كيفيت زندكى بازنشسـتخان رابطـهـ مثبـت و معنادار داشت (1) - (1).

يكى ديخر از عوامل مرتبط با كيفيت زندگى، حمايست اجتمـاعى است. مفهـوم حمايـت اجتمـاعى بــه حمايست از منظـر ارزيـابى شناختى فرد از محيط و روابطش با ديخــران مسى نخــــ. نظريـهـ يردازان حمايت اجتماعى معتقدند تمام روابطى كه فرد با ديخران برقرار مى كند، حمايت اجتماعى محسوب نمى شود، مخــر آنكـهـ فرد آنها را به عنوان منبعى مناسـب يـا در دسـترس بـراى رفـع نيازهاى خود بداند (T) (I). كاهى كمك هايى كه به فرد مى شـود نامناسب يا خلاف ميل فرد است كه اين موارد حمايت محسـوب نمى شوند. در نتيجه حمايت اجتماعى بر ارزيابى شناختى فـرد از
افزايش طول عمر و اميد به زندگى موجب يديده سالمندى شـده

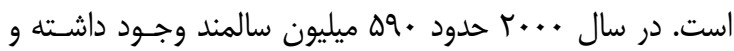
يشي بينى مى شود كه تا سال هr •r تعداد سالمندان از مرز يك ميليارد و يكصد ميليون نفر تجاوز كند ((). طبـق ارزيـابى واحـد جمعيت سازمان ملل، جمعيت سـالمندان در كشـورهاى در حـال توسعه به سرعت در حال افزايش بوده و ييش بينى مى شود كه تعداد آنها در سال •ه •r به دو ميليارد نفر برسد و در ايران طبق آمار سال • وسا، r/ א درصد از جمعيت را سالمندان تشكيل دادند (T). با توجه بــه افـزايش تعـداد سـالمندان مســائل و مشـكلات حمايتى، اجتمـاعى، توانبخشى، بهراشـتى و درمـانى آنـان نيـز افزايش مى يابد، لذا بررسى كيفيت زنـدگى آنهـا اهميـت فـوق

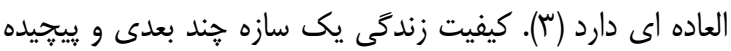
به معناى ادراك از وضعيتى كه افراد در آن زنـدكى مسى كنـــد و ادراك از زمينه فرهنگَى و نظام ارزشى كه در آن قرار دارند، مـى باشد كه اين ادراك بر اسـاس اهـداف، انتظـارات، اسـتاندارها و علائق آنها است (أ). امروزه كيفيت زندگى يك مفهـوم فراگيـر است كه از سلامت فيزيكى، رشد شخصى، حالات روانشـناختى، سطح استقلال، روابط اجتماعى و روابـط بـا نهادهـاى برجسـته محيط تاثير مى بذيرد و بـر ادراك فـرد مبتـى اسـت. در واقـع كيفيت زندگى گستره ایى شامل ابعاد عينى و ذهنى است كـه در تعامل با يكديگر مى باشند (ه). از مهمترين عوامل روانشناختى مرتبط با كيفيت زندگى مى توان به سرمايه اجتماعى، حمايت اجتماعى و سخت رويى روانشناختى اشاره كرد. سرمايه اجتماعى مفهوم نسبتا جديدى اسـت كـهـ بــه ويزگى هاى سازمان اجتمـاعى از قبيـل شـبكه هـا، هنجارهـا و اعتماد اجتماعى اشاره مى كند و به دنبال مزاياى دو جانبه مى 
رسيدند خشم با كيفيت زندگى رابطه معنادار منفى و سخت رويى

روانشناختى با كيفيت زندگى رابطه معنادار مثبت داشت (س؟). با اينكه يزوهش هاى قبلى به بررسى رابطه سـرمايه اجتمـاعى، حمايت اجتماعى و سخت رويى روانشناختى بـا كيفيـت زنسدكى اشاره داشتند، اما يكى از نارسائى هاى اصلى اين مطالعات عـدم توجه به نقش همزمان اين متغيرها در ييش بينى كيفيت زندكَى زنان سالمند بـود. همجنـين هـيج مطالعـه اى بـهـ بررسـى ايسن متغيرها در يِيش بينى كيفيت زندگى زنان سالمند نيرداخته است. با توجه به اينكه سالمندان قشر آسيب يذيرى هسـتند و كيفيـت زندگى نقش مهمى در زندگى آنان دارد، هدف كلى اين يثروهش بررسى نقش سرمايه اجتماعى، حمايت اجتماعى و سخت رويسى روانشناختى در ييش بينى كيفيت زندكى زنان سالمند بود.

\section{مواد و روش ها}

اين يزوهش توصـيفى تحليلـى از نـوع همبسـتخى بـود. جامعــه آمارى آن همه زنان سالمند شهر قرجى در سـال عqسا بودنـد.

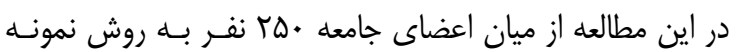
گيرى خوشه اى انتخاب شدند. معيارهاى ورود بـه مطالعـه سـن بالاى هاء سال و بالاتر، توانايى خواندن و نوشتن و عدم سكونت در خانه سالمندان بود. همجنين معيارهاى خروج از مطالعه عـدم موافقت كتبى جهت شركت در يزوهش و عدم توانايى خواندن و نوشتن بود.

ابزار كَردآورى داده ها شـامل ع بخــش مـى باشـــ. بخـش اول شـامل يرسشـنامه سـرمايه اجتمـاعى بـود كـهـ توسـط Pajak

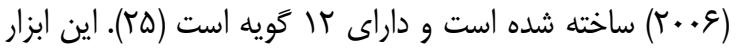
با استفاده از مقياس ينج درجه ایى ليكرت از يـك تـا هـنج نمـره كذارى مى شود. نمره ابـزار بــا جمـع كـردن نمـره كَيـهـ هـا و
محيط و اطمينان از در دسـترس بـودن حمايـت متمركـز اسـت (1).) حمايت اجتماعى به فرد احساس ارزشمند بودن مى دهد و حمايت اجتماعى به عنوان ميزان برخوردارى از محبت، همراهى و توجه اعضاى خانواده، دوستان و ساير افراد تعريــف مسى شـود (أl). نتايج يثرهش ها حاكى از رابطه مثبـت و معنـادار حمايست اجتماعى با كيفيت زندگى بودند (1)-ها). بـراى مثـال Wu و همكاران (Q1 +r) ضـمن بثروهشى دربـاره حمايست اجتمـاعى و كيفيت زندگى به اين نتيجه رسيدند حمايت اجتماعى با كيفيـت زندگى رابطه مستقيم و معنادار داشت (10). همجنين جليليـان و

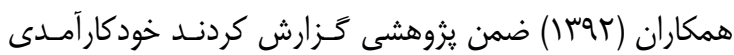
عمومى و حمايت اجتماعى درك شده با كيفيـت زنـدگى رابطـهـ مثبت و معنادار داشتند (1) (1). يكى ديخر از عوامل مـرتبط بـا كيفيـت زنسـدَى، سـخت رويسى روانشناختى است. سخت رويى يك مولفه شخصيتى است كه به عنوان يك منبع مقاومت در مواجهه با حوادث تنش زاى زنـدگى عمل مى كند (19). افراد سخت رو قـدرت كنتـرل بيشـترى بـر رويدادها دارند و به جاى دورى از مشـكلات آنهـا را بـهـ عنـوان فرصت يِشرفت ارزيابى مى كنند (•r). همجنين سخت رويى در حفظ سلامت، بهبود عملكرد و كيفيت زندگى مـوثر اسـت (آT). نتايج يزوهش ها حاكى از رابطه مثبت و معنـادار سـخت رويسى

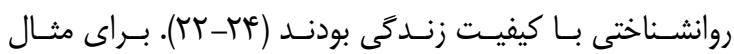
Gharehzad Azari درباره رابطه سخت رويى با اضطراب و كيفيت زنـدكى بـهـ ايـن نتيجه رسيدند سخت رويى با اضطراب رابطه معكوس و معنـادار و با كيفيت زندگى رابطه مستقيم و معنادار داشت (Tr). همجنين

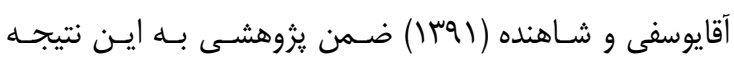


نمره كَويه ها و ميانكين كَرفتن از آنها بدست مى آيد و هـر حهـهـ نمره آزمودنى بيشتر باشد، يعنى داراى سخت رويى روانشـناختى بيشترى است. Kobasa (19v9) ضمن تاييد روايى سازه ابزار،

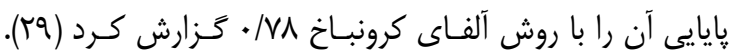
همجِنين سورى و عاشورى (وqجا) بايايى ابزار را با روش آلفاى كرونباخ سم/• كزارش كردند (•r). در اين مطالعه ضريب پايايى اين برسشنامه با روش آلفاى كرونباخ •1/ • محاسبه شد. بخش جهارم شامل برسشنامه كيفيـت زنـــى بـود كـه توسط

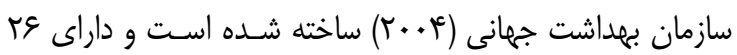
كَويه است (ا). اين ابزار بـا اسـتفاده از مقيـاس يـنج درجـه اى ليكرت از يك تا ينج نمره كذارى مى شود. نمره ابـزار بـا جمـع

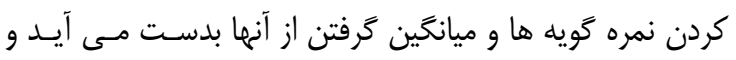

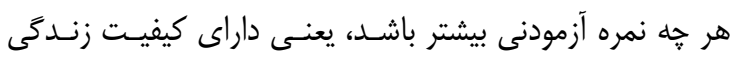

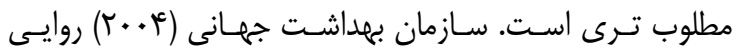
محتوايى ابزار را تاييد و پايـايى آن رادر كشـورهاى مختلـف بـاـ روش آلفاى كرونباخ بالاتر از • •/ •زارش كـرد (1). همجنـين يورافكارى و همكـاران (سوسا) بِايـايى ابـزار را بـا روش آلفــى

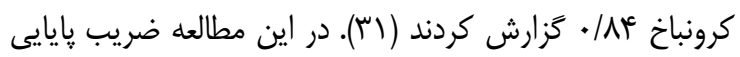
اين يرسشنامه با روش آلفاى كرونباخ VD/ محاسبه شد. يس از مشخص شدن اعضاى نمونـهـ و قبـل از تكميـل كـردن يرسشنامه هـا، ابتـدا هــف يـروهش و ســـس اصـل رازدارى و محرمانه ماندن اطلاعات شخصى براى آنها بيان و در نهايـت از آنان رضايت نامه شركت آكاهانه در يزوهش دريافـت شـــ. لازم به ذكر است كه داده هـا بـا روش هـاى همبسـتخى يبرسـون و ركر سيون جندكانه با مدل كام به كام تجزيه و تحليل شدند كـه براى اين منظور از نرم افزار SPSS-19 استفاده شد.
ميانكَين كَرفتن از آنها بدست مى آيد و هر خـهـ نمـره آزمـودنى بيشـتر باشــ، يعنسى داراى سـرمايه اجتمـاعى بيشـترى اسـت.

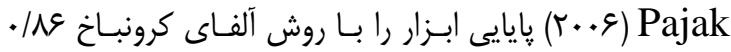
كزارش كرد و روايى ابزار را با مفاهيم اعتمـاد اجتمـاعى تعمـيم يافته، تساهل اجتماعى، نكخرش مثبت نسبت به برون كَروه هـا و عدم تعصب نسبت به درون گروه ها بررسى نمود و بيان كرد كه ابزار همان مفهومى را منعكس مى كند كه بايد سـنجيده شـود، يعنى از روايى خوبى برخوردار است (Tه). همجنين اديبى سده و

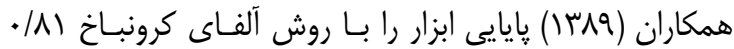
كزارش كردند (ع؟). در اين مطالعه ضريب پايايى اين برسشنامه با روش آلفاى كرونباخ VN/ محاسبه شد. بخش دوم شامل يرسشنامه حمايست اجتمـاعى بـود كـهـ توسـط و و همكاران (1991) ساخته شده است و داراى rا گَويه است (TV). اين ابزار با استفاده از مقياس ينج درجه اي ليكرت از يكى تا ينج نمره كذارى مى شود. نمره ابزار با جمع كـردن نمـره كويه ها و ميانكَين كرفتن از آنها بدست مى آيد و هر جـه نمـره آزمودنى بيشتر باشد، يعنى داراى حمايت اجتماعى بيشترى است.

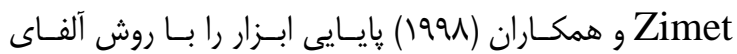
كرونباخ זq/· كزارش كردندو روايى صورى و محتوايى ابـزار را تاييد كردند (TV). همجنين بيرامس و همكاران (سوسا) بإيايى

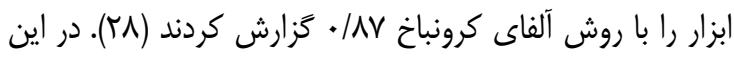
مطالعه ضريب پايايیى ايـن يرسشـنامه بــا روش آلفـاى كرونبـاخ

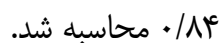
بخش سوم شامل برسشنامه سخت رويى روانشـناختى بـود كـه توسط Kobasa (19v9) ساخته شده اسـت و داراى •ه كَيـــ است (9ף). اين ابزار با استفاده از مقياس جهار درجه اى ليكـرت از يك تا جهار نمره كذارى مى شود. نمره ابزار بـا جمـع كـردن 


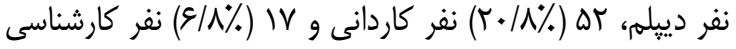
بودند. شاخص هاى توصيفى ميـانخين، انحـراف معيـار و دامنــه تغييرات متغيرهاى سرمايه اجتماعى، حمايـت اجتمـاعى، سـخت رويى روانشناختى و كيفيت زندگى زنان سالمند در جدول ا ارائه شده است. جدول الـ آماره هاى توصيفى سرمايه اجتماعى، حمايت اجتماعى، سخت رويى روانشناختى و كيفيت زندگى زنان سالمند

\begin{tabular}{|c|c|c|c|c|}
\hline بيشترين مقدار & كمترين مقدار & انحراف معيار & ميانغَين & متغير ها \\
\hline$r / 91$ & $1 / 41$ & . /Va & 要 & سرمايه اجتماعى \\
\hline Tr/א & $1 / T \Delta$ & $\cdot /$ A & $r / q F$ & حمايت اجتماعى \\
\hline$r / / f$ & I/GT & . /At & T/AF & سخت رويى روانشناختى \\
\hline$r / 1 Q$ & $1 / 19$ & $1 / .9$ & $r / \mathcal{H}$ & كيفيت زندَّى \\
\hline
\end{tabular}

بودن براى همه متغيرها برقرار است. همجنين مقدار عامل تورم واريانس براى همه متغيرهاى ييش بين كمتر از r مى باشد كـه از • ا بسيار كمتر است، بنابراين فرض هم خطى بودن جندگانسه رد مى شود. علاوه بــر آن مقــدار دوربـين - واتسـون برابـر بـاــا I/VAF مى باشد كه از • و ع فاصله زيادى دارد، بنابراين فـرض همبستخى يسماندها نيز رد مى شود. با توجه به نكاتى كـه ذكـر

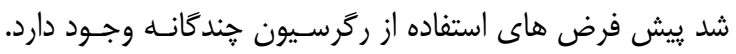
براى بررسى روابط ميان سـرمايه اجتمـاعى، حمايـت اجتمـاعى، سخت رويى روانشناختى و كيفيت زندكى زنان سالمند از ضرايب همبستخى ييرسون استفاده شد كه نتـايج آن در جـدول r ارائهـ شده است.

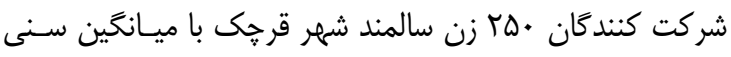

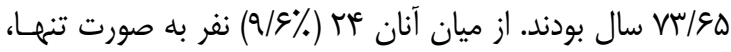

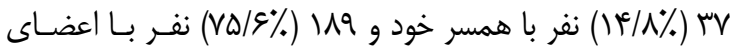
خانواده زندگى مى كردند. همجنين از نظر سطح تحصـيلات 19

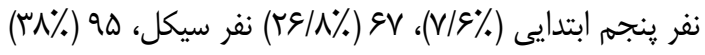


جدول r. ضرايب همبستكى سرمايه اجتماعى، حمايت اجتماعى، سخت رويى روانشناختى و كيفيت زندكى زنان سالمند (•ra)

\begin{tabular}{|c|c|c|c|c|}
\hline كيفيت زندكى & سخت رويى روانشناختى & حمايت اجتماعى & سرمايه اجتماعى & متغير \\
\hline & & & 1 & سرمايه اجتماعى \\
\hline & & 1 & $\cdot / K f^{F^{*}}$ & حمايت اجتماعى \\
\hline & 1 & $\cdot / T V^{\text {管 }}$ & 烈 & سخت رويى روانثناختى \\
\hline 1 &.$/ / q^{* * *}$ & $\cdot / \Delta r^{* * *}$ & $\cdot / 48^{* * *}$ & كيفيت زندكى \\
\hline
\end{tabular}

$* * \mathrm{p}<\cdot 1 \cdot 1$

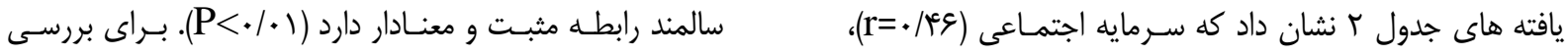

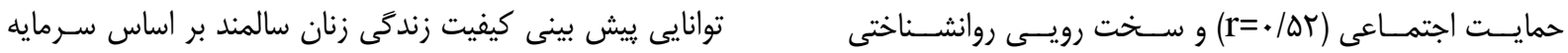

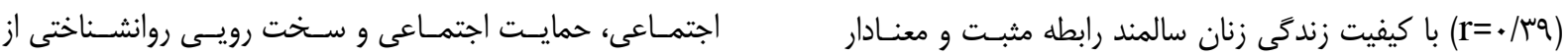

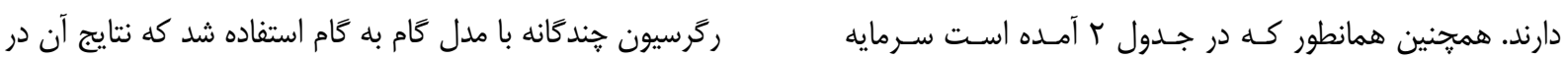
اجتماعى با حمايت اجتماعى و سخت رويسى روانشـناختى زنـان ارائه شده است. سالمند و حمايت اجتماعى بـا سـخت رويسى روانشـناختى زنـان جدول س. نتايج ركرسيون خندكانه كيفيت زندگى زنان سالمند بر اساس سرمايه اجتماعى، حمايت اجتماعى، سخت رويى روانشناختى

\begin{tabular}{|c|c|c|c|c|c|c|c|c|}
\hline معنادارى & df2 & df1 & Fغيير F & تغيير R & $\mathbf{R}^{2}$ & $\mathbf{R}$ & متغير هاى ييش بين & 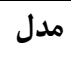 \\
\hline $.1 \cdot .1$ & MrA & 1 & sT/KYA & $\cdot / T r r$ & $\cdot / T V$ & . & حمايت اجتماعى & 1 \\
\hline$\cdot 1 \cdot \cdot 1$ & MeV & 1 & $1 \% / 9 \Delta \cdot$ & 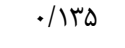 & $\cdot / 4 \cdot 1$ & . $/ 8$ सq & حمايت اجتماعى و سرمايه اجتماعى & $r$ \\
\hline \multirow[t]{2}{*}{.$/ \cdot \cdot 1$} & TrE & 1 & $9 / V+1$ & .1 .98 & $\cdot 10 \cdot 4$ & $\cdot / \mathrm{VI}$ & حمايت اجتماعى، سرمايه اجتماعى و & r \\
\hline & & & & & & & سخت رويى & \\
\hline
\end{tabular}

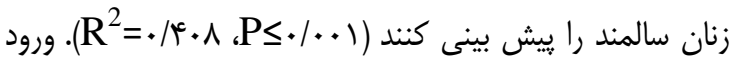
متغير سرمايه اجتماعى توانست ه/سا درصد توان پـيش بينسى را افزايش دهد. در مدل سوم يس از حمايـت اجتمـاعى و سـرمايه اجتماعى، سخت رويى روانشـناختى وارد معادلـه شـد و ضـريب همبستخى اين سه متغير با كيفيت زندكى • • ب • بود و اين سـه متغير توانسـتند ع/٪•ه درصـد از تغييـرات كيفيـت زنـدكى زنـان

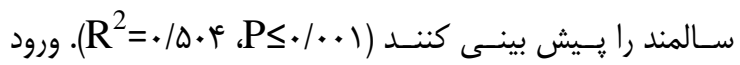
سخت رويى روانشناختى توانست \&/9 درصد توان ييش بينسى را
يافته هاى جدول س نشان داد كه در مدل اول حمايت اجتمـاعى بيشترين نقش را در ييش بينـى كيفيـت زنسدگى زنـان سـالمند داشت. ضريب همبستگى اين متغير با كيفيت زندگى سזه/ • بود و اين متغير توانست س/ TV درصد از تغييرات كيفيت زندگى زنان

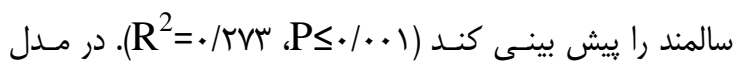
دوم يس از حمايت اجتماعى، سرمايه اجتماعى وارد معادله شد و ضريب همبستخى اين دو متغير با كيفيت زنسدكى وسوع/ • بـود و اين دو متغير توانستند ^/•ا درصـد از تغييـرات كيفيـت زنـدگى 


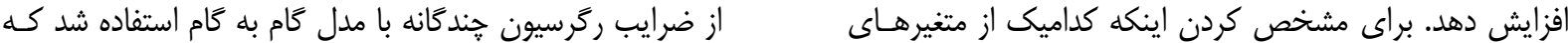

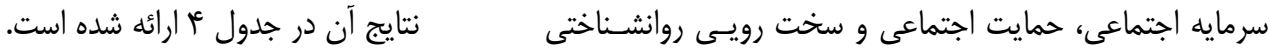
توانايى بيشترى در ييش بينى كيفيت زندگى زنان سالمند دارنسـ جدول ع. ضرايب استاندارد و غيراستاندارد ركرسيون هندكانه با مدل كام به كام براى ييش بينى كيفيت زندگى زنان سالمند

\begin{tabular}{|c|c|c|c|c|c|c|}
\hline \multirow[t]{2}{*}{ معنادارى } & \multirow[t]{2}{*}{$\mathbf{T}$} & \multicolumn{3}{|c|}{ ضرايب رَّرسيون } & \multirow[t]{2}{*}{ متغير هاى ييش بين } & \multirow[t]{2}{*}{ مدل } \\
\hline & & B B استاندارد شده & انحراف استاندارد & غير استاندارد B & & \\
\hline.$/ . .1$ & $q / \cdot \Delta \Delta$ & . / Fva &.$|19|$ & $1 / \uparrow \Delta \Lambda$ & حمايت اجتماعى & 1 \\
\hline.$/ \cdot 1$ & V/NAC & ונז/. &.$/ \mathrm{WV}$ & $1 / r q 4$ & حمايت اجتماعى & $r$ \\
\hline.$/ . \cdot 1$ & $D / T F I$ & 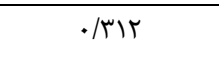 &.$/ 1 r$. & . /9т9 & سرمايه اجتماعى & \\
\hline $.1 \cdot .1$ & $V / \cdot 9 V$ & . MTY &.$/ 190$ & $1 /$ rAF & حمايت اجتماعى & \\
\hline$\cdot 1 \cdot \cdot 1$ & $r / r \Delta \Lambda$ & $\cdot / r \cdot V$ & $\cdot / r \cdot 9$ & $\cdot|9 \wedge|$ & سرمايه اجتماعى & \\
\hline$. \cdot . r$ & $1 / 949$ & . MFA & ع פT/. & . /8тq & حمايت اجتماعى & \\
\hline
\end{tabular}

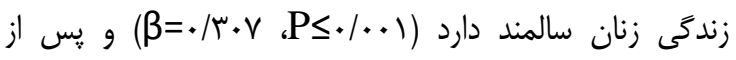
حمايت اجتماعى و سرمايه اجتماعى، سخت رويى روانشناختى با

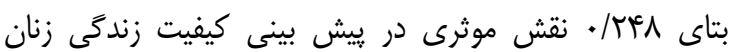

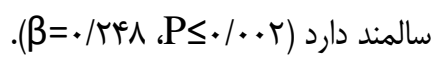

يافته هاى جدول fا نشان داد كه در مدل سوم حمايت اجتماعى با بتاى عبس/· بيشترين سهم را در ييش بينى كيفيت زندگى

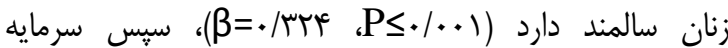

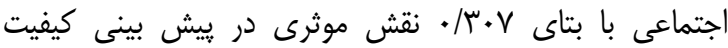

\section{بحث و نتيجه كَيرى}

شبكه هايى از ييوندهاى اجتماعى هستند و باعث دور هم جمـع شدن افراد به صورت منسجم و با ثبات به منظور تحقق هـدفى مشترى مى شوند كه اين عوامل نخست باعث افزايش كارآمدى و اعتماد به نفس و در نهايت باعث افزايش كيفيت زنسدگى مسى شوند. تبيين ديگر اينكه سرمايه اجتماعى جمع منـابع بـالقوه اي است كه حاصل شبكه هاى بادوام روابط كم و بيش نهادينه شده در رَروه ها است. شبكه اى كه هر يك از اعضـاى را پشـتيبانى مى كند و آنان را مستحق اعتبار مى سازد و هر جقدر افراد اعتبار
بررسى ويزگى هاى روانشناختى زنان سالمند به خصوص بررسى كيفيت زندگى آنان با توجـهـ بـهـ مسـائل و مشـكلات حمـايتى، اجتماعى، توانبخشى، بهداشتى و درمـانى اهميـت فراوانى دارد. نتايج اين يزوهش نشان داد سرمايه اجتماعى با كيفيـت زنسدكى زنان سالمند رابطه مثبت و معنادار داشت كه اين يافته بـا يافتـه يزوهش هاى قبلى همسو بود (1) (19). در تبيين اين يافتـه مسى توان كَت سرمايه اجتماعى منبعسى از ميـراث روابـط اجتمـاعى است و فعاليت هاى جمعى را تسهيل مى كند و دربر گيرنده 
افراد قدرت كنترل وقـايع زنـدكى را دارنــــ و بـهـ جـاى دورى از مشكلات، آنها را به عنوان فرصت ييشرفت ارزيابى مى كنند كه اين عوامل باعث افزايش كيفيت زندگى آنان مسى شـوند. تبيسين ديخر اينكه افراد با سخت رويى بالا در مقايسه با افراد با سـخت رويى پايين رويدادهاى تنش زا را مثبت تـر و قابـل كنتـرل تـر

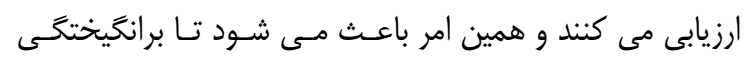
فيزيولوزيكى كه در اثر ارزيابى منفى رويدادها ايجاد مسى شـود و

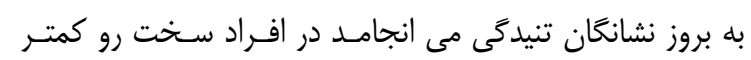
باشد كه اين امر باعث افزايش كيفيت زندكى افراد سخت رو مى

علاوه بر آن نتايج نشان داد در يكى مدلى كه سرمايه اجتماعى، حمايت اجتماعى و سخت رويى روانشـناختى بـه طـور همزمـان براى ييش بينى كيفيت زندگى رقابت نمايند به ترتيـب حمايـت اجتماعى، سرمايه اجتماعى و سـخت رويسى روانشـناختى نقـش مستقيم و موثرى در ييش بينـى كيفيـت زنـدكى زنـان سـالمند داشتند. در اين مدل متغيرهاى ييش بين توانستند أ •ه درصد از تغييرات كيفيت زندكى زنان سالمند را ييش بينى كنــد. در ايسن مدل مشخص شد كه حمايت اجتماعى بالاترين وزن استاندارد را داشت. يֶ آنجه در بيش بينى كيفيت زندگى نقـش عمـده اى ايفا مى كند در درجه نخست حمايت اجتماعى است. يعنى اينكه ميزان ارزيابى افراد درباره محبـت، همراهـى و توجـه از محـيط، اعضاى خانواده، دوستان و ساير افراد حقدر است. نخستين و مهمترين محدوديت ايـن مطالعـه، مشـكلات ذهنس ذهنى و جسمى سالمندان بود كه باعث مشـكلاتى در مشـاركت

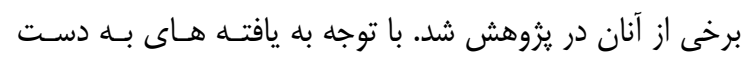
آمده ييشنهاد مى شود مشاوران و درمانكَران براى بهبود كيفيت زندگى زنان سالمند، از طريـق كارگَاه هـاى آموزشى سـرمايه
بيشترى داشته باشند، كمتر دجار تـنش و اسـترس مسى شـوند، بيشتر از راهبردهاى مقابله اى سازگًار استفاده مى كنند و جـالش هاى زندَّى را بهتر حل مى كنند كه اين عوامل باعث افزايش

$$
\text { كيفيت زندگى مى شوند. }
$$

نتايج ديخر اين يثوهش نشان داد كه حمايت اجتماعى با كيفيت زندگى زنان سالمند رابطه مثبت و معنادار داشت كه اين يافته بـا يافته يزوهش هاى قبلى همسـو بـود (1)-ها). در تبيـين ايـن يافته مى توان كَفت حمايت اجتماعى مى تواند مانــــــــرى در مقابل حوادث و رويدادهاى تنش زا باشد كه انزوا را كاهش مسى دهد و در فرد احساس عزت نفس و ارزشمندى ايجاد مى كنـــ و هر جه دريافت شخص از ميزان حمـايتى كـه از سـوى ديخـران دريافت مى كند بيشتر باشد به همان اندازه از سلامت و رضايت از زندكَى بالاترى بجره منــد مسى شـود كـهـ ايـن عوامـل باعث افزايش كيفيت زندگى مى شـوند. تبيـين ديخـر اينكـه حمايست اجتماعى باعث مى شـود فـرد احسـاس كنــــــه مـورد علاقـهـ ديخران است، از وى مراقبت مسى شـود، ارزش و احتـرام دارد و متعلق به شبكه اى از ارتباطات است. هر جقدر اين شبكه هـاى

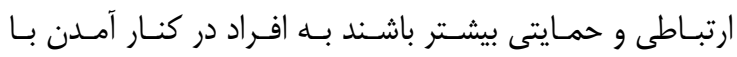
فشارهاى محيطى كمك بيشترى مى كنــــ و بــه لحـاظ روانسى افراد را در موقعيتى آرامش بخش قرار مى دهند كه اين عوامـل باعث افزايش كيفيت زندگى مى شوند. همجنين نتايج ديخر نشان داد كه سخت رويسى روانشـاختى بـا كيفيت زندگى زنان سالمند رابطه مثبت و معنادار داشت كه ايـن

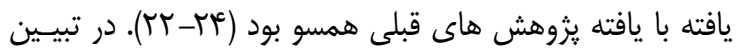
اين يافته مى توان گفت افراد سخت رو داراى گروهى از ويزگى هاى شخصيتى هستند كـهـ بــهـ عـــوان يـــ منبـع مقاومـت در مواجها با رويدادهاى استرس زا عمل مى كنـــ. همجنــين ايـن 


$$
\text { تقدير و تشكر }
$$

در پايان از كليه سالمندان شهر قرجى كه بـا صـبر و شـكيبايى

خود ما را در انجام اين يزوهش حمايت كردند، صميمانه تشكر و

$$
\text { قدردانى مى شود. }
$$

اجتماعى، حمايت اجتماعى و سخت رويسى روانشـناختى آنـان را

بهبود بخشند و برنامه ريزان به نشـانه هـاى متغيرهـاى مـذكور

توجه كرده و بر اساس آنها برنامه هايى را بـراى بهبـود كيفيـت

زندگى زنان سالمند طراحى كنند. همجنين ييشنهاد مى شود اين

يُزوهش در زنان ساير شهرها و مردان سالمند انجـام شـود و بـا

نتايج مطالعه حاضر مقايسه كردد.

\section{- References}

1. World Health Organization. The world health organization quality of life (WHOQOL)BREF. Geneva: World Health Organization; 2004.

2. Borji M, Jahani S, Shiri P, Azami A. [Assessing the status of sleep quality in elderly city of Ilam in 2015]. Journal of Geriatric Nursing 2016; 2(3): 44-53. (Persian)

3. Danesh MJ, Chang AL. The role of the dermatologist in detecting elder abuse and neglect. Journal of the American Academy of Dermatology 2015; 73(2): 285-293.

4. Uysal M, Sirgy MJ, Woo E, Kim H. Q uality of life (QOL) and well-being research in tourism. Tourism Management 2016; 53(4): 244-261.

5. Cepeda-Valery B, Cheong AP, Lee A, Yan BP. Measuring health related quality of life in coronary heart disease: The importance of feeling well. International Journal of Cardiology 2011; 149(2): 4-9.

6. Kowalski CH, Ommen O, Driller E, Ernstmann N, Wirtz MA, et al. Burnout in nurses the relationship between social capital in hospitals and emotional exhaustion. Journal of Clinical Nursing 2010; 19: 1654-1663.

7. Kouvonen A. Low workplace social capital as a predictor of depression: the finish public sector study. American Journal of Epidemiology 2008; 10: 213-226.

8. Rothon C, Goodwin L, Stansfeld S. Family social support, community social capital and adolescents' mental health and educational outcomes: a longitudinal study in England. Social Psychiatry Epidemiology 2011; 2: 94-108.

9. Hamdan H, Yusof F, Marzukhi MA. Social capital and quality of life in urban neighborhoods high density housing. Social and Behavioral Science 2014; 153(10): 169179.

10. Hu F, Niu L, Chen R, Ma Y, Qin X, Hu Z. The association between social capital and quality of life among type 2 diabetes patients in Anhui province, China: a cross-sectional study. Public Health 2015; 10: 15-21. 
11. Alizadeh-Aghdam M, Soltani-Bahram S, Alizadeh-Aghdam R. [Relationship between social capital and the quality of life in University of Tabriz retirees]. Journal of Management and Development Process 2013; 26(3): 63-78. (Persian)

12. Chadwick KA, Collins PA. Examining the relationship between social support availability, urban center size, and self-perceived mental health of recent immigrants to Canada: a mixed-methods analysis. Social Science \& Medicine 2015; 128: 220-230.

13. Charyton C, Elliott JO, Lu B, Moore JL. The impact of social support on health related quality of life in persons with epilepsy. Epilepsy Behavior 2009; 16(4): 640-645.

14. Xu J, Ou L. Resilience and quality of life among henchman earthquake survivors: the mediating role of social support. Public Health 2014; 128(5): 430-437.

15. Wu X, Chen J, Huang H, Liu Z, Li X, Wang H. Perceived stigma, medical social support and quality of life among people living with HIV/AIDS in Hunan, China. Applied Nursing Research 2015; 28(2): 169-174.

16. Paterson C, Jones M, Rattray J, Lauder W. Exploring the relationship between coping, social support and health-related quality of life for prostate cancer survivors: A review of the literature. European Journal of Oncology Nursing 2013; 17(6): 750-759.

17. Shareh H, Soltani E, Ghasemi A. [Prediction of quality of life of non-insulin dependent diabetic patients based on perceived social support]. Zahedan Journal Research Medicine Science 2012; 14(2): 82-85. (Persian)

18. Jalilian M, Mostafavi F, Sharifirad G. [Relation between general self-efficacy and perceived social support with quality of life in heart-coroner patients: a cross-sectional study]. Journal of Health System Research 2013; 19(5): 531-539. (Persian)

19. Delahaij A, Gaillard C, Van Dam P. Hope and Hardiness as related to life satisfaction. The Journal of Positive Psychology 2010; 3(8): 171-179.

20. Bahamin GH, Taheri F, Moghaddas AR, Sohrabi F, Dortaj F. The effects of hardiness training on suicide ideation, quality of life and plasma levels of lipoprotein in patients with depressive disorder. Social and Behavioral Sciences 2012; 46: 4236-4243.

21. Maddi SR. Hardiness: The courage to grow from stresses. Journal of Positive Psychology 2006; 1: 160-168.

22. Gharehzad Azari M, Ghorban Shirudi SH, Khalatbari J. Relationship of hardiness training with anxiety and quality of life of pregnancy women. Social and Behavioral Sciences 2013; 84(9): 1785-1789. 
23. Aghayousefi A, Shahandeh M. [The relationship between anger, psychological hardiness and quality of life in coronery heart disease patients]. Health Psychology 2012; 1(3): 1-11. (Persian)

24. Aubi S, Teimory S, Nayyeri M. [Hardiness, quality of life and well-being]. Developmental Psychology: Iranian Psychologists 2010; 6(24): 353-360. (Persian)

25. Pajak K. A tool for measuring bridging social capital. Proceedings of the research network for the sociology of culture conference, Ghent: Belgium Het 2006; 3: 15-17.

26. Adibisade M, Yazdkhasti B, Rabbani Khorasgani A, Lotfizade A. [Assessment of inter group social capital]. Social Welfare 2010; 10(3): 193-220. (Persian)

27. Zimet GD, Dahlem NW, Zimet SG, Farley GK. The multidimensional scale of perceived social support. Journal of Personality Assessment 1998: 52: 30-41.

28. Beyrami M, Movahedi Y, Movahedi M. [The relationship between perceived social support and the feeling of social-emotional loneliness with internet addiction in University students]. Social Cognition 2014; 3(3): 109-121. (Persian)

29. Kobasa SC. Stressful life events, personality and health: An inquiry into hardiness. Journal of Personality and Social Psychology 1979; 37: 1-11.

30. Souri A, Ashoori J. [The relationship between perceived social support, psychological hardiness and family communication patterns with quality of life among patients with type II diabetes]. Journal of Nursing Diabetes 2015; 3(2): 53-65. (Persian)

31. Pourakbari F, Khajevand Khoshli A, Asadi J. [Relationship of psychological hardiness and quality of life with death anxiety in nurses]. Journal of Research Development Nursing \& Midwifery 2014; 11(2): 53-59. (Persian) 